\title{
Effects of edible coatings on quality maintenance of fresh-cut nectarines
}

\author{
Valentina Chiabrando*, Giovanna Giacalone \\ DISAFA, Department of Agriculture, Forest and Food Science, Largo Braccini 2, Grugliasco (TO), Italy
}

\section{A B S T R A C T}

\begin{abstract}
The study was conducted to investigate the behavior of three different edible coatings formulations on the overall postharvest quality of ready to eat Orion nectarines under fresh-cut commercial storage conditions. Three different coatings were used: $1.5 \%$ (w/v) sodium alginate coating, $2 \%(\mathrm{w} / \mathrm{v})$ chitosan coating and a solution of $1.5 \%(\mathrm{w} / \mathrm{v})$ of chitosan and $1 \%(\mathrm{w} / \mathrm{v})$ sodium alginate. Fresh-cut nectarines variations in color, flesh firmness, total soluble solids content (TSSC), $\mathrm{pH}$, titratable acidity (TA) and polyphenol oxidase (PPO) activity were measured. Moreover microorganism counts of molds and yeasts were analyzed. The results indicated that treatments with alginate inhibited decrease in firmness, titratable acidity and delayed flesh browning. Furthermore alginate inhibited the PPO activity throughout the storage period considered. Chitosan coating reduced microorganism proliferation of molds and yeasts compared to control treatment. Our study recommends that alginate edible coating treatment may be a desirable method to maintain fresh-cut nectarines quality and to improve nectarines postharvest life.
\end{abstract}

Keywords: Alginate; Chitosan; Orion; Polyphenol oxidase activity

\section{INTRODUCTION}

The consumer request of ready to eat vegetables and fruit has increased due to changes of lifestyle based on the demand for hale and healthy foods, together with the busy lifestyle. However, mechanical operations like washing, sorting, peeling and slicing or chopping necessary to produce fresh-cut fruits products, damage fruit soft tissues and consequently limit their postharvest life (Chiabrando and Giacalone, 2013; Oms-Oliu et al., 2010). Then freshcut fruits are more delicate than the whole. The main aspects that affect the acceptance or not of the consumer being discoloration of the tissues, flesh browning and texture, dehydration and water losses. For these reasons, fruit processing companies needs the advance of different postharvest practices able to maintaining safety, shelf-life and to preserve the visual and organoleptic fresh-like characteristics of fruits.

A current method to extend and improved the shelf-life of minimally processed fruit and vegetables is the use of edible coatings. Edible coatings makes a semipermeable barrier to $\mathrm{O}_{2}, \mathrm{CO}_{2}$ and water, with the consequent reduction of weight losses, respiration rate and enzymatic browning (Correa-Betanzo et al., 2011). The basic constituents of coatings for fruit and vegetables are lipids, proteins and polysaccharides. These coatings are directly applied on the superficial part of minimally processed or whole fruit or vegetables. There is a lot of polymers that have been used as coatings for fruit and vegetables, like sodium alginate, gellan, carboxymethyl cellulose, chitosan and whey and soy proteins (Chiabrando and Giacalone, 2013; NavarroTarazaga et al., 2008; Rojas-Grau et al., 2009; Reinoso et al., 2008). Maintenance of quality has been reached using chitosan coating in peaches and nectarines (Chiabrando and Giacalone, 2013; Li and Yu, 2001), pectin coating in melons (Ferrari et al., 2013), sodium alginate in apples and blueberries (Chiabrando and Giacalone, 2015; Maftoonazad et al., 2008; Olivas et al., 2007), hydroxypropylmethyl cellulose and proteins in plums (Navarro-Tarazaga et al. 2008; Reinoso et al., 2008).

Nectarines have high functional and qualitative parameters, but the realization of products based on minimally processed nectarines has limited from their very short shelf-life due to browning of the cut surface and to an

\footnotetext{
*Corresponding author:

Valentina Chiabrando, Department of Agriculture, Forest and Food Science, Largo Braccini 2, Grugliasco (TO), Italy.

E-mail: valentina.chiabrando@unito.it, Telephone: 0039011 6708938, Fax: 00390116708658
}

Received: 22 September 2015; 
excessive flesh softening after the process. For this reason, edible coating during storage could be used as a treatment to extend and maintain visual and organoleptic quality of fresh-cut nectarines.

Limited information are accessible on organoleptic changes of fresh-cut nectarines in response to edible coatings treatments, therefore, the objective of this research is to evaluate the effects of three coatings on the overall quality of nectarine slices cv Orion, under fresh-cut commercial storage conditions.

\section{MATERIALS AND METHODS}

\section{Fruits}

Orion Nectarines (Prunus persica (L.) Batsch.) were harvested at commercial maturity, and stored $\left(0^{\circ} \mathrm{C}\right.$ and $95 \%$ relative humidity, $\mathrm{RH}$ ) before processing. To obtain ready to eat nectarines, eight slices were cut around the stone from each fruit.

\section{Coating solutions}

Three coatings solutions were prepared. A 2\% (w/v) acidsoluble chitosan (Sigma-Aldrich Co., Steinhein, Germany) solution was equipped by dissolving acid-soluble chitosan in $1 \%$ acetic acid aqueous added with $50 \%$ glycerol and 0.15\% Tween 20 (w/v) according to Duan et al. (2011). The coating was homogenized for $90 \mathrm{~s}$ and then stored for 12 hours at room temperature. Slices were then dipped for three minutes in the coating and then dried in air at room temperature for about thirty minutes.

A $1.5 \%(\mathrm{w} / \mathrm{v})$ sodium alginate (Sigma-Aldrich Co., Steinhein, Germany) coating was prepared dissolving the alginate in deionized water upon moving at $70^{\circ} \mathrm{C}$ for two hours. Then the solution was cooled to $25^{\circ} \mathrm{C}$ according to Poverenov et al. (2014). After dipping the slices in alginate coating for two minutes, samples were immersed in 5\% aqueous solution of $\mathrm{CaCl}_{2}$ for three minutes (Sigma-Aldrich Co., Steinhein, Germany) to help gelation by cross-linking of sodium alginate particles. The samples then were dried in air at room temperature for about thirty minutes.

A $1.5 \%(\mathrm{w} / \mathrm{v})$ chitosan and $1 \%(\mathrm{w} / \mathrm{v})$ sodium alginate solution was set with $3 \%$ chitosan solution and $2 \%$ sodium alginate solution at a 1:1 ratio with $25 \%$ glycerol and $0.15 \%$ Tween $20(\mathrm{w} / \mathrm{v})$ according to the method of Duan et al. (2011). Slices were dipped in this coating solution for three minutes and then dried in air at room temperature for about thirty minutes.

Control samples were dipped in water and then air dried.

For each coating treatment (alginate, chitosan, alginate + chitosan and control) nine packages were set.
Polyethylene (PE) bags ( $20 \mathrm{~cm} \times 30 \mathrm{~cm}$ size and $39 \mu$ thickness) with $50 \mathrm{~cm}^{3} \mathrm{O}_{2} / \mathrm{m}^{2} /$ bar/day and $15 \mathrm{~g} / \mathrm{m}^{2} /$ bar/day water vapor transmission rate (Sealed, Italy) were used. Each package contained 15 slices $(150 \mathrm{~g})$. The packages were sealed (UNIMEC packaging systems, Italy) and stored in darkness in a low temperature storage room for 8 days $\left(4^{\circ} \mathrm{C}, 95 \% \mathrm{RH}\right) \cdot 4^{\circ} \mathrm{C}$ is the temperature usually used in Italian supply chain, although $0^{\circ} \mathrm{C}$ was establish to be the best temperature for the shelf-life of minimally processed nectarines (Gorny et al., 1999).

\section{Atmosphere composition}

Headspace concentrations of $\mathrm{O}_{2}$ and $\mathrm{CO}_{2}$ of the packages were observed at day 3, 6 and 8 during storage and analyzed using a Check- Point gas analyzer (PBI Dansensor, Italy). At each storage time and for each treatment were analyzed three bags. Samples of headspace atmospheres were taken with a syringe through silicone septa positioned to the film. The headspace atmosphere of the bags were determined with a paramagnetic sensor for $\mathrm{O}_{2}$ concentration and an infrared sensor for $\mathrm{CO}_{2}$ concentration. The instrument has been calibrated towards atmosphere. Results has expressed as $\mathrm{kPa}$ of $\mathrm{O}_{2}$ and $\mathrm{CO}_{2}$ inside the packages.

\section{Quality evaluations}

Physicochemical quality attributes of nectarines slices were measured at the beginning of the testing (time 0 ) and at the end ( 8 days).

TSSC $\left({ }^{\circ}\right.$ Brix), $\mathrm{pH}$ and TA (meq/l) were analyzed using juice from five slices blended at high speed in a homogenizer. TSSC was determined by a digital refractometer (Atago refractometer,PR-32, Co., Ltd, Japan) and the concentrations expressed as ${ }^{\circ}$ Brix. TA and $\mathrm{pH}$ were analyzed by the titration of the juice, using $0.1 \mathrm{~N}$ $\mathrm{NaOH}$ and an automatic titrator (Compact 44-00, Crison Instruments SA, Barcelona, Spain). Three replicates were made (five slices each) for each coating treatment.

Textural measurements were carried out individually on 15 slices for each coating treatment at the beginning of the experiment (time 0 ) and after 3 and 8 days of storage. Nectarines samples were cooled at about $20^{\circ} \mathrm{C}$ for 3 hours before the analysis. Bourne (1980) explained that in most fruit and vegetables firmness decrease with the increasing of the temperature. Slices firmness was determined by a penetration test using a Texture Analyzer TaxT2 $\mathrm{i}^{\circledR}$ (Stable Micro System, UK). Measurements were performed in the equatorial part of the slice, at a crosshead speed of $3 \mathrm{~mm} / \mathrm{s}$ and with a $3 \mathrm{~mm}$ diameter probe (Chiabrando et al., 2009). A 5-Kg load cell has been used for firmness determination and the probe was programmed to penetrate $3 \mathrm{~mm}$ into the slice. The maximum penetration force $(\mathrm{N})$, which has 
been related to the firmness, was the parameter selected for the statistical analysis of data.

Color of coated slices was measured individually in 15 slices for each coating treatment at the beginning of the experiment and then at day 3, 6 and 8 of storage. Surface color was analyzed with a Minolta Chroma Meter CR-400 (Konica Minolta, Osaka, Japan) with the illumining D75 and an observation angle of $10^{\circ}$ and calibrated with a standard white plate. Color was expressed as changes in $\mathrm{L}^{*}$ (lightness), $\mathrm{h}^{\circ}$ (hue angle), $\mathrm{b}^{*}$ (yellow) and $\mathrm{a}^{*}$ (green) coordinates during cold storage.

\section{Browning potential (BP) and polyphenol oxidase (PPO) activity}

BP was determined as described by Arias et al. (2008), with some modification at day 3 and 8 of storage. The extract was obtained as follows: $10 \mathrm{~g}$ of nectarines was homogenized for $2 \mathrm{~min}$ at $13.500 \mathrm{rpm}$ with an Ultra-Turrax T25 (IKAs WERKE, Germany), centrifuged (Centrifuge AVANTITM J-25, Beckman Instruments Inc., Fullerton, CA, USA) for $10 \mathrm{~min}$ at $4000 \mathrm{rpm}$ and filtered through Whatman 4 paper (Whatman Intl., UK). The absorbance of the clear juice was measured spectrophotometrically (Hitachi, U-5100, Japan) at $440 \mathrm{~nm}$. Three replicates were made (five slices each) for each coating treatment.

The determination of the PPO activity was performed at day 3 and 8 of cold storage at $4^{\circ} \mathrm{C}$ as described by SolivaFortuny et al. (2001).

Enzyme extraction. $50 \mathrm{~g}$ of nectarines was mixed with a buffer solution $(1: 1)$ at $\mathrm{pH}=6.5$ contained $\mathrm{NaCl}$ 1M (Sigma-Aldrich Chemie, Steinheim, Germany) and 5\% polyvinylpolypyrrolidone (Sigma-Aldrich Chemie, Steinheim, Germany). The sample was blended, homogenized with an Ultra Turrax T25 (IKAs WERKE, Germany) and centrifuged for $30 \mathrm{~min}$ at $12000 \mathrm{rpm}$ at $4^{\circ} \mathrm{C}$ (Centrifuge AVANTITM J-25, Beckman Instruments Inc., U.S.A.). The supernatant was filtered through Whatman 1paper (Whatman Intl., U.K.) to obtain the enzymatic extract, which was used for the analysis.

PPO activity measurement. PPO activity was analyzed spectrophotometrically with the addition of $3 \mathrm{~mL}$ of $0.05 \mathrm{M}$ catechol (Sigma-Aldrich Chemie, Steinheim, Germany) and $75 \mu \mathrm{L}$ of the enzymatic extract to a 4.5 $\mathrm{mL}$ quartz cuvette (1 $\mathrm{cm}$ path length). The absorbance (Beckman Du ${ }^{\mathbb{B} 530}$ spectrophotometer) were recorded at $400 \mathrm{~nm}$ every $5 \mathrm{~s}$ up to 3 minutes from the time that the enzyme extract was added to the catechol solution. One unit of PPO activity was defined as a change in absorbance of $0.0010 / \mathrm{min} * \mathrm{~mL}$ of the extract. The initial reaction rate was estimated from the linear portion of the plotted curve.
For each coating treatment, three replicates of samples were made.

\section{Microbiological analysis}

To estimate the microbiological efficiency of the coatings, microbiological analyses of yeasts and molds were carried out at the end of cold storage ( 8 days), as described by the Compendium of Methods for the Microbiological Examination of Foods (Vanderzant and Splittstoesser, 1992). Molds and yeast counts were performed using a chloramphenicol glucose agar (CGA) (ISO 21527, 2008). All the plates were incubated at room temperature for 3-5 days. Data were obtained for each measurement in three replicates for each treatment. Microbiological counts were expressed as colony forming units (CFU) $\mathrm{g}^{-1}$ of sample.

\section{Statistical analysis}

Data were subjected to analysis of variance (ANOVA) using statistical procedures of the STATISTICA ver. 6.0 (Statsoft Inc., Tulsa, OK, USA) and the means were compared by Tukey's HSP test (honest significant differences). Source of variation was coating treatments. Mean values were considered significantly different at $p \leq 0.05$.

\section{RESULTS AND DISCUSSION}

\section{Atmosphere composition}

Gas composition inside the samples bags is an important parameter which reflects the fruits respiration, transpiration and decay grade of samples. Tapia et al. (2008) described that the rate of respiration and transpiration increases by 1-7 times in processing fruits. Changes in $\mathrm{O}_{2}$ and $\mathrm{CO}_{2}$ concentrations in the samples packages during the 8 days of storage were showed in (Figs. 1 and 2). Significant $(p<0.05)$ changes in $\mathrm{O}_{2}$ and $\mathrm{CO}_{2}$ concentration were detected between coated and control samples during cold storage period. After 3 days of storage, the $\mathrm{O}_{2}$ concentration was lower $(p<0.05)$ in uncoated samples compared with coated nectarines, but not at the end of storage, where the $\mathrm{O}_{2}$ values were not significantly different amongst all samples. The $\mathrm{O}_{2}$ concentration in the headspace of the samples bags was: alginate $>$ alginate + chitosan $>$ chitosan $>$ control. The trend and order was reversed for $\mathrm{CO}_{2}$ concentration. These results suggest that sodium alginate practices a barrier for the exchanges of gases, isolating the coated product from the environment. Comparable results have been available for coatings based on sodium alginate and chitosan in fresh-cut papaya, mango or apples (Chien et al., 2007; Roja-Grau, 2007; Tapia et al., 2008).

\section{Quality evaluations}

Sugar in fruits play an important role with organic acids in the organoleptic properties of fruits, besides having a metabolic function. Considering the TSSC, decreases 
in this quality parameters of coated and uncoated slices were observed with storage (Table 1). A corresponding progressive decrease is probably due to the ordinary metabolism of the cells. The decrease was higher in chitosan and sodium alginate samples and lower in control and in alginate + chitosan coated slices. This changes were also reported by Maftoonazad et al. (2008) in peaches coated with alginate and by Valero et al. (2013) in plums.

Organic acid content of the fruits decreases during ripening due to the respiratory metabolism. Therefore, the change in organic acid concentration is a good indicator for observing ripening phases because the higher the metabolic respiration, the higher would be the decay of acidity content. In this work, titratable acidity of nectarine slices declined significantly $(p<0.05)$ during storage period (Table 1). The decay in acidity was fewer in sodium alginate coated samples related to the other samples. In particular, the edible coating with sodium alginate delayed the changes in acidity content probably due to a lower respiration rate. In fact, the tendencies of changes in the acid contents were similar to those of $\mathrm{O}_{2}$ concentration (Fig.1). The same result was obtained also in plums with edible coating (Valero et al., 2013).

The $\mathrm{pH}$ values remained quite stable in the range of 5.064.76 in all the treatments, with no significant differences amongst all the treatments (Table 1).

Variations in fruit firmness values have been associated with ripening processes and is one of the most significant quality parameters of fresh-cut postharvest fruit quality

Table 1: Effects of edible coating on overall quality (TSSC, TA and $\mathrm{pH}$ ) of nectarine slices at the end of storage period ( 8 days)

\begin{tabular}{llll}
\hline Treatment & TSSC $\left({ }^{\circ}\right.$ Brix) & TA (meq/l) & pH
\end{tabular}

\begin{tabular}{llll}
\hline Fruits before the treatment & $9.45 \pm 0.13$ & $138.05 \pm 0.02$ & $4.19 \pm 0.01$
\end{tabular}

Control $\quad 8.90 \pm 0.25$ a $\quad 98.18 \pm 6.32$ b $\quad 5.01 \pm 0.24$

Sodium alginate $\quad 8.00 \pm 0.32$ b $\quad 114.54 \pm 4.52$ a $\quad 4.76 \pm 0.71$

Chitosan $\quad 7.83 \pm 0.57$ b $104.40 \pm 5.55$ b $5.06 \pm 0.50$

Sodium alginate+chitosan $\quad 9.25 \pm 0.25$ a $\quad 105.70 \pm 7.45$ b $\quad 4.93 \pm 0.32$

TSSC: Total soluble solids content; TA: Titratable acidity. Each value is the mean of three replicate measurements \pm standard deviation $( \pm S D)$. Different letters in the same column means significantly different $(p \leq 0.05)$. Column without letters means no significant differences

Table 2: Effects of edible coating on texture $(\mathrm{N})$ of nectarine slices during post-harvest storage period

\begin{tabular}{lccc}
\hline Texture (N) & \multicolumn{3}{c}{ Days of storage } \\
\cline { 2 - 4 } & $\mathbf{0}$ & $\mathbf{3}$ & $\mathbf{8}$ \\
\hline Control & $4.63 \pm 0.71$ & $6.92 \pm 0.91 \mathrm{~b}$ & $7.42 \pm 0.82 \mathrm{a}$ \\
Sodium alginate & $4.63 \pm 0.71$ & $7.21 \pm 0.97 \mathrm{ab}$ & $7.59 \pm 0.63 \mathrm{a}$ \\
Chitosan & $4.63 \pm 0.71$ & $7.51 \pm 0.81 \mathrm{a}$ & $6.91 \pm 0.59 \mathrm{~b}$ \\
Sodium alginate+chitosan & $4.63 \pm 0.71$ & $6.91 \pm 0.49 \mathrm{~b}$ & $6.87 \pm 0.75 \mathrm{~b}$
\end{tabular}

Each value is the mean of 15 replicate measurements \pm standard deviation $( \pm S D)$. Different letters in the same column means significantly different $(p \leq 0.05)$. Column without letters means no significant differences
(Dhall, 2013). Preservation of fruit firmness is important to determine acceptability of minimally processed nectarines and to maintain the shelf-life of the product. Mean comparison revealed that the control slices and coated with $1.5 \%$ sodium alginate registered, after 8 days of storage, the maximum firmness values with value of about $7.59 \mathrm{~N}$ (Table 2). After 8 days of storage, neither chitosan nor chitosan+alginate coatings preserved the original (time 0 ) firmness values. Respiration is the main reason for these changes. Decrease in respiration rate reduces ripening and, for this reason, limits the detrimental reduction in fruit firmness according to the results in fresh-cut apples (Rojas-Grau et al., 2007), in strawberry and in papaya pieces (Fan et al., 2009; Narsaiah et al., 2015). Moreover, sodium alginate acts as an obstacle to water transference, delaying dehydration and, consequently, improving the fruit firmness of the coated fruits.

To evaluate color changes during storage of nectarine slices, colorimetric parameters of hue angle $\left(\mathrm{h}^{\circ}\right)$ and lightness $\left(\mathrm{L}^{*}\right)$ were evaluated and showed on Table $3 . \mathrm{H}^{\circ}$ is a good indicator of color variations during shelf-life of fruit

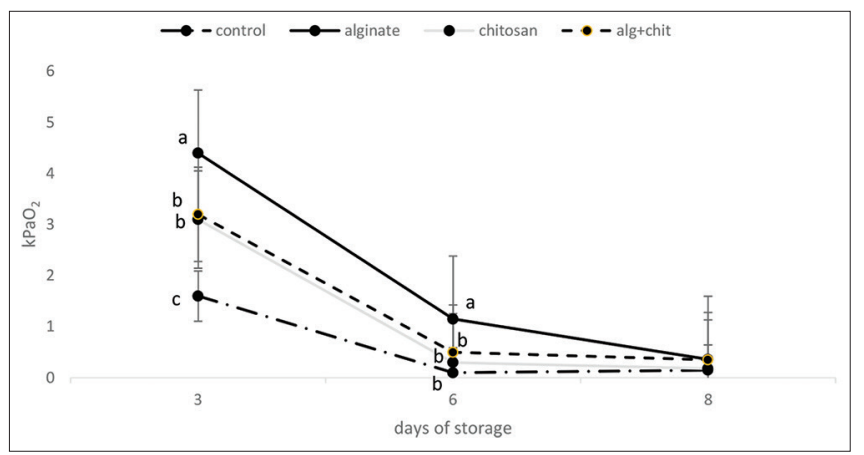

Fig 1. $\mathrm{O}_{2}$ concentration $\left(\mathrm{kPa} \mathrm{O} \mathrm{O}_{2} \pm \mathrm{SD}\right)$ inside fresh-cut nectarine slices packages during storage. Each symbol is the mean of three replicate measurements; vertical lines represent standard deviation $( \pm S D)$. Different letters in the same storage time means significantly different $(p \leq 0.05)$.

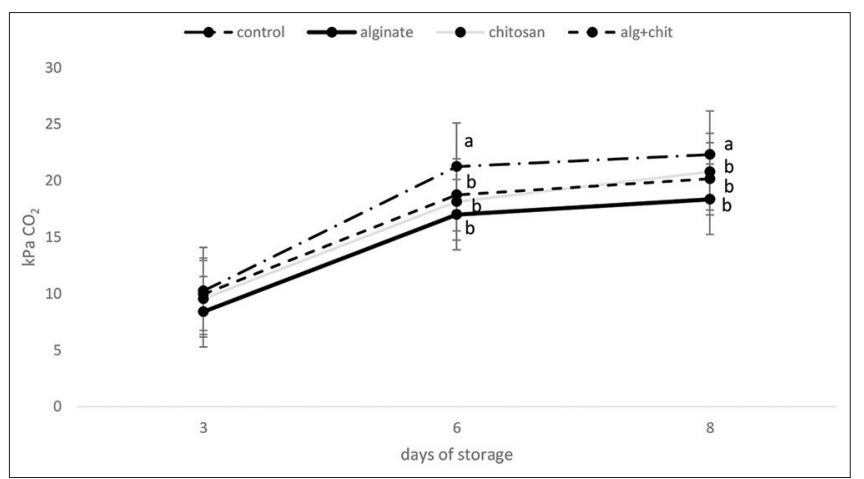

Fig 2. $\mathrm{CO}_{2}$ concentration $\left(\mathrm{kPa} \mathrm{CO} \mathrm{CO}_{2} \pm \mathrm{SD}\right)$ inside fresh-cut nectarine slices packages during storage. Each symbol is the mean of three replicate measurements; vertical lines represent standard deviation $( \pm S D)$. Different letters in the same storage time means significantly different $(p \leq 0.05)$. 
because it incorporates two color parameters $\left(a^{*}\right.$ and $\left.b^{*}\right)$ (Greer, 2005). During storage period, the decrease in $\mathrm{L}^{*}$ and $h^{\circ}$ values reflects the increase of tissue browning. In this study, $\mathrm{L}^{*}$ decrease slowly during storage, in particular in chitosan coated slices and control (Table 3). At the end of storage period, samples coated with alginate and alginate + chitosan showed significant $(p>0.05)$ lower $\mathrm{L}^{*}$ values. These lower values can be explained by the film opacity of sodium alginate coating that probably changes the surface reflection properties. In this sense, is probable that alginate film turned opaque during film formation, resulting in lower $\mathrm{L}^{*}$ values.

At harvest, the $\mathrm{h}^{\circ}$ was 97.9 and decrease very slowly during storage. After 8 days of storage, $\mathrm{h}^{\circ}$ remained quite stable in the range of 95.02-93.03, with no significant differences between treatments (Table 3).

\section{Browning potential and polyphenol oxidase activity}

Tissues browning of fruit and vegetables decreases visual quality and is often the factor that limit the shelf-life and then the merchantability of minimally processed products. $\mathrm{BP}$ increased or remained quite stable over the 8 days of cold storage. The lowest BP values were observed in chitosan samples and the highest in control nectarine slices, after 3 days of storage (Table 4). After 8 days of storage, sodium alginate coated slices showed the lowest browning values related to other nectarines samples.

The primary enzyme responsible of the browning reaction is the polyphenol oxidase. This enzyme catalyze the hydroxylation of monophenols to o-diphenols and the oxidation of o-diphenols to their equivalent o-quinones (Zhou et al., 2016). In the present work, PPO activity of minimally processed nectarines samples with edible coatings decreased throughout storage period (Table 4).

\begin{tabular}{|c|c|c|c|c|}
\hline & \multicolumn{4}{|c|}{ Days of storage } \\
\hline & 0 & 3 & 6 & 8 \\
\hline \multicolumn{5}{|l|}{$\mathrm{L}^{*}$} \\
\hline Control & $69.97 \pm 4.52$ & $70.08 \pm 6.43$ & $67.92 \pm 5.84$ & $65.51 \pm 5.26 \mathrm{a}$ \\
\hline Sodium alginate & $69.97 \pm 4.52$ & $63.24 \pm 3.89$ & $63.35 \pm 2.25$ & $62.67 \pm 4.59 b$ \\
\hline Chitosan & $69.97 \pm 4.52$ & $68.47 \pm 3.55$ & $67.65 \pm 3.32$ & $67.56 \pm 4.59 \mathrm{a}$ \\
\hline $\begin{array}{l}\text { Sodium alginate+ } \\
\text { chitosan }\end{array}$ & $69.97 \pm 4.52$ & $65.39 \pm 4.76$ & $62.11 \pm 3.43$ & $60.06 \pm 3.29 \mathrm{~b}$ \\
\hline \multicolumn{5}{|l|}{$h^{*}$} \\
\hline Control & $97.9 \pm 1.69$ & $96.08 \pm 2.87$ & $95.85 \pm 1.95$ & $95.02 \pm 1.87$ \\
\hline Sodium alginate & $97.9 \pm 1.69$ & $97.54 \pm 1.85$ & $97.51 \pm 2.39$ & $95.78 \pm 3.64$ \\
\hline Chitosan & $97.9 \pm 1.69$ & $93.38 \pm 1.85$ & $93.16 \pm 2.46$ & $93.03 \pm 4.59$ \\
\hline $\begin{array}{l}\text { Sodium alginate+ } \\
\text { chitosan }\end{array}$ & $97.9 \pm 1.69$ & $97.41 \pm 2.52$ & $94.81 \pm 1.81$ & $94.74 \pm 2.30$ \\
\hline
\end{tabular}

Each value is the mean of 15 replicate measurements \pm standard deviation $( \pm S D)$. Different letters in the same column means significantly different $(p \leq 0.05)$. Column without letters means no significant differences
In particular, we noticed that PPO activity values were dissimilar depending on the type of edible coating used, in particular chitosan coated samples showed significant higher PPO activity. Sodium alginate is effective in controlling PPO activity during storage and delaying flesh browning of nectarine slices during storage, according to the results of $\mathrm{BP}$.

\section{Microbiological analyses}

Fresh-cut fruit and vegetables are more susceptible to microbial decay if related to whole fruit, due to lesions caused during minimally processing (Rojas-Grau et al., 2009). In addition, due to the high quantity of humidity and organic sugar present on the substrate of the fruit, minimally processed nectarines are a favorable condition for microorganisms to grow. The counts for yeasts and molds after 8 days of cold storage is showed in Table 5 . The chitosan coated samples registered lower microbial spoilage than the other samples. On the contrary, in sodium alginate samples the growth of microorganisms was the highest, with values of $3.28 \log \mathrm{CFU} \mathrm{g}^{-1}$ for yeasts. Microbiological standards (IFST, 1999) for non-thermal minimally processed fruit specified that a count of $6 \log \mathrm{CFU} \mathrm{g} \mathrm{g}^{-1}$ of yeast and molds is tolerable at all the points of the supply chain of fruit products. Our microbiological results showed that yeast and molds counts did not exceed these points in any samples. In particular, chitosan edible coating

Table 4: Effects of edible coating on browning potential and polyphenoxidase activity of nectarine slices during post-harvest storage period

\begin{tabular}{lcc}
\hline & \multicolumn{2}{c}{ Days of storage } \\
\cline { 2 - 3 } & $\mathbf{3}$ & $\mathbf{8}$ \\
\hline Browning potential (Abs $440 \mathrm{~nm})$ & $1466 \mathrm{a}$ & $1330 \mathrm{a}$ \\
$\quad$ Control & $0.601 \mathrm{~b}$ & $0.561 \mathrm{~b}$ \\
Sodium alginate & $0.316 \mathrm{~b}$ & $1260 \mathrm{a}$ \\
Chitosan & $0.666 \mathrm{~b}$ & $1268 \mathrm{a}$ \\
$\quad$ Sodium alginate+chitosan & & \\
Relative PPO activity & $0.101 \mathrm{~b}$ & $0.061 \mathrm{~b}$ \\
Control & $0.079 \mathrm{~b}$ & $0.029 \mathrm{~b}$ \\
Sodium alginate & $0.338 \mathrm{a}$ & $0.092 \mathrm{a}$ \\
Chitosan & $0.047 \mathrm{~b}$ & $0.028 \mathrm{~b}$ \\
Sodium alginate+chitosan &
\end{tabular}

Each value is the mean of three replicate measurements \pm standard deviation $( \pm S D)$. Different letters in the same column means significantly different $(p \leq 0.05)$

Table 5: Effects of edible coating on microbial growth ( $\log$ CFU g ${ }^{-1}$ of fruit) of nectarine slices at the end of storage period

\begin{tabular}{lcc}
\hline & Yeasts (log CFU/g) & Molds (log CFU/g) \\
\hline Sodium alginate & $3.28 \mathrm{a}$ & $<1$ \\
Sodium alginate+chitosan & $2.52 \mathrm{~b}$ & $<1$ \\
Chitosan & $<1 \mathrm{c}$ & $<1$ \\
Control & $1.96 \mathrm{~b}$ & $<1$ \\
\hline
\end{tabular}

Different letters in the same column means significantly different $(p \leq 0.05)$. Column without letters means no significant differences 
minimized the development of yeasts and effectively inhibited the growth of microorganisms during postharvest period according to Chien et al. (2007) in mango, Gonzalez-Aguilar et al. (2009) in papaya and HernandezMunoz et al. (2006) in strawberry. On the contrary, results indicated also that sodium alginate might stimulate the microbial proliferation, because the microbial counts in these samples were even higher than control. This effect was also found in the study of Benitez et al., (2015) on kiwi fruit slices.

\section{CONCLUSION}

In conclusion, sodium alginate coating treatment would provide the best compromise to maintain the quality attributes of fresh-cut nectarines by reducing respiration rate, preventing the tissue softening and maintaining the acidity and the TSSC during storage. These coating is also effective in controlling the activity of browning related enzymes compared to the chitosan coating slices and control. The chitosan coating reduced microorganism counts compared to control, resulting in a better maintenance of safety of the fresh-cut products. Although the sodium alginate coating does not minimize the growth of yeasts, the levels are acceptable also after 8 days of cold storage. Considering our results, the sodium alginate treatment represent a possible alternative for postharvest handling of fresh-cut nectarines with the objective to preserve the organoleptic quality of the fruit during storage and to delay the inevitable ripening process.

\section{Declaration of interest}

The authors report no conflicts of interest. The authors alone are responsible for the content and writing of this article.

\section{Authors' contributions}

V.C and G.G. have an equal contribution to the paper. Study concept and management: G.G.. Conducted the experiments: V.C.. Analysis and interpretation of data: V.C., G.G. Drafting of manuscript: V.C.. Critical revision: G.G..

\section{REFERENCES}

Arias, E., J. Gonzalez, P. Lopez-Buesa and R. Oria. 2008. Optimization of processing of fresh-cut pear. J. Sci. Food Agric. 88: 1755-1763.

Beaulieu, J. C. and E. A. Baldwin. 2002. Flavor and aroma of freshcut fruits and vegetables. In: O. Lamikanra (Ed.), Fresh-cut Fruits and Vegetables, CRC Press, Florida, Pp. 391-425.

Benítez, S., I. Achaerandio, M. Pujolà and F. Sepulcre. 2015. Aloe vera as an alternative to traditional edible coatings used in freshcut fruits: A case of study with kiwifruit slices. LWT - Food Sci. Technol. 61: 184-193.
Bourne, M. C. 1980. Textural evaluation of horticultural crops. Hortic. Sci. 15: 51-56.

Chiabrando, V., G. Giacalone and L. Rolle. 2009. Mechanical behaviour and quality traits of high bush blueberry during postharvest storage. J. Sci. Food Agric. 89: 989-992.

Chiabrando, V. and G. Giacalone. 2013. Effect of different coatings in preventing deterioration and preserving the quality of fresh-cut nectarines (cv Big Top). J. Food. 11: 285-292.

Chiabrando, V. and G. Giacalone. 2015. Anthocyanins, phenolics and antioxidant capacity after fresh storage of blueberry treated with edible coatings. Int. J. Food Sci. Nutr. 66: 248-253.

Chien, P. and F. Sheu. 2007. Effects of edible chitosan coating on quality and shelf life of sliced mango fruit. J. Food Eng. 78: 225-229.

Correa-Betanzo, J., J. K. Jacob, G. Perez-Perez. and G. Paliyath. 2011. Effect of a sodium caseinate edible coating on berry cactus fruit (Myrtillocactus geometrizans) phytochemicals. Food Res. Int. 44: 1897-1904.

Dhall, R. 2013. Advances in edible coatings for fresh fruits and vegetables: A review. Crit. Rev. Food Sci. Nutr. 53: 435-450.

Duan, J., R. Wu, B. C. Strik and Y. Zhao. 2011. Effect of edible coatings on the quality of fresh blueberries (Duke and Elliott) under commercial storage conditions. Postharvest Biol. Technol. 59: 71-79.

Fan, Y., Y. Xu, D. Wang, L. Zhang, J. Sun, L. Sun and B. Zhang. 2009. Effect of alginate coating combined with yeast antagonist on strawberry (Fragaria $\times$ Ananassa) preservation quality. Postharvest Biol. Technol. 53: 84-90.

Ferrari, C. C. and C. I. G. L. Sarantoulos. 2013. Effect of osmotic dehydration and pectin edible coatings on quality and shelf life of fresh-cut melon. Food Bioprocess Technol. 6: 80-91.

Gonzalez-Aguilar, G. A., E. Valenzuela-Soto, J. Lizardi-Mendoza, F. Goycoole, M. A. Martinez-Tellez, M. A. Villegas-Ochoa, I. N. Monroy-Garcia and J. F. Ayala-Zavala. 2009. Effect of chitosan coating in preventing deterioration and preserving the quality of fresh-cut papaya 'Maradol'. J. Sci. Food Agric. 89: 15-23.

Gorny, J. R., B. Hess-Pierce and A. A. Kader. 1999. Quality changes in fresh-cut peach and nectarine slices as affected by cultivar, storage atmosphere and chemical treatments. J. Food Sci. 64 : 429-432.

Greer, D.H. 2005. Non-destructive chlorophyll fluorescence and colour measurements of 'Braeburn' and 'Royal Gala' apple (Malus domestica) fruit development throughout the growing season. N. Z. J. Crop Hortic. Sci. 33: 413-421.

Hernandez-Munoz, P., E. Almenar, M. J. Ocio and R. Gavara. 2006. Effect of calcium dips and chitosan coatings on postharvest life of strawberries (Fragaria $x$ ananassa). Postharvest Biol. Technol. 39: 247-253.

IFST. 1999. Microbiological Criteria for Foods. Institute of Food Science and Technology, London.

ISO 21527. 2008. International Organization for Standardization Publications. Microbiology of food and animal feeding stuffs. Horizontal Method for the Enumeration of Yeasts and Molds.

$\mathrm{Li}, \mathrm{H}$. and T. Yu. 2001. Effect of chitosan coating on incidence or brown rot, quality and physiological attributes for postharvest peach fruit. J. Sci. Food Agric. 81: 269-274.

Maftoonazad, N., H. S. Ramaswamy and M. Marcotte. 2008. Shelf life extension of peaches through sodium alginate and methyl cellulose edible coatings. Int. J. Food Sci. Technol. 43: 951-957.

Narsaiah, K., R. A. Wilson, K. Gokul, H. M. Mandge, S. N. Jha, S. Bhadwal, R. K. Anurag and R. K. Malik. 2015. Effect of bacteriocin-incorporated alginate coating on shelf-life of 
minimally processed papaya (Carica papaya L.). Postharvest Biol. Technol. 100: 212-218.

Navarro-Tarazaga, M.L.L., R. Sothornvit and M. G. Pérez Gago. 2008. Effect of plasticizer type and amount on hydroxypropyl methylcellulose-beeswax edible film properties and postharvest quality of coated plums (cv. Angeleno). J. Agric. Food Chem. 56: 9502-9509.

Olivas, G. I., D. S. Mattinson and G. V. Barbosa Cánovas. 2007. Alginate coatings for preservation of minimally processed Gala apples. Postharvest Biol. Technol. 45: 89-96.

Oms-Oliu, G., M. A. Rojas-Graü, L. Alandes, P. Varela, R. SolivaFortuna, I. Hernando, I. Pérez Munuera, S. Fiszman and O. Martín-Belloso. 2010. Recent approaches using chemical treatments to preserve quality of fresh-cut fruit: A review. Postharvest Biol. Technol. 57: 139-148.

Pérez-Gago, M. B., M. Serra and M. A. del Río. 2006. Color changes of fresh-cut apples coated with whey protein concentrate-based edible coatings. Postharvest Biol. Technol. 39: 84-92.

Poverenov, E., S. Danino, B. Horev, R. Granit, Y. Vinokur and V. Rodov. 2014. Layer-by-layer electrostatic deposition of edile coating on fresh-cut melon model: Anticipated and unexpected effect of alginate-chitosan combination. Food Bioprocess Technol. 7: 1424-1432.

Reinoso, E., G. S. Mittal and L. T. Lim. 2008. Influence of whey protein composite coatings on plum (Prunus domestica L.) fruit quality. Food Bioprocess Technol. 1: 314-325.

Rojas-Grau, M.A., R. M. Raybaudi-Massilia, R. C. Soliva-Fortuny, R.
J. Avena-Bustillos, T. H. McHugh and O. Martın-Belloso. 2007. Apple puree-alginate edible coating as carrier of antimicrobial agents to prolong shelf-life of fresh-cut apples. Postharvest Biol. Technol. 45: 254-264.

Rojas-Grau, M. A., R. Soliva-Fortuny and O. Martın-Belloso. 2009. Edible coatings to incorporate active ingredients to freshcut fruits: a review. Trends Food Sci. Technol. 20: 438-447.

Soliva-Fortuny, R. C., N. Grigelmo-Miguel, I. Odrizola-Serrano, S. Gorinstein and O. Martin-Belloso. 2001. Browning evaluation of ready-to-eat apples as affected by modified atmosphere packaging. J. Agric. Food Chem. 49: 3685-3690.

Tapia, M. S., M. A. Rojas-Grau, A. Carmona, F. J. Rodriguez, R. Soliva-Fortuny and O. Martin-Belloso. 2008. Use of alginate and gellan-based coatings for improving barrier, texture and nutritional properties of fresh-cut papaya. Food Hydrocoll 22: 1493-1503.

Valero, D., H. M. Díaz-Mula, P. J. Zapata, F. Guillén, D. MartínezRomero, S. Castillo and M. Serrano. 2013. Effects of alginate edible coating on preserving fruit quality in four plum cultivars during postharvest storage. Postharvest Biol. Technol. 77: 1-6.

Vanderzant, C. and D. F. Splittstoesser. 1992. Compendium of Methods for the Microbiological Examination of Foods. 3rd ed. American Public Health Association (APHA), Washington, p. 1219.

Zhou, L., W. Liu, Z. Xiong, L. Zou, J. Chen, J. Liu and J. Zhong. 2016. Different modes of inhibition for organic acids on polyphenoloxidase. Postharvest Biol. Technol. 199: 439-446. 